\title{
Effect of Grafting onto Different Rootstocks and some Foliar Applications on Cucumber Production under High Polyethylene Tunnel Conditions. Dawa, K. K. ${ }^{1}$; E. E. Metwaly ${ }^{1}$ and A. A. Omar ${ }^{2}$ \\ ${ }^{1}$ Vegetable and Floriculture Department, Faculty of Agriculture, Mansoura University, Egypt. \\ ${ }^{2}$ Expertise Sector, Justice Ministry.
}

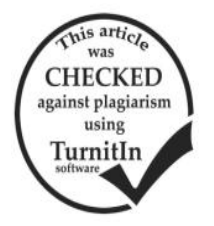

\section{ABSTRACT}

Field experiments were carried out in two successive seasons during the winter seasons of 2014/2015 and 2015/2016 under high polyethylene tunnels in a private farm located in Belqas District, Dakahlia Governorate, Egypt. The aim of this study is to improve the fruit yield and quality of the grafted cucumber (Cucumis sativus .L) c.v Nabeela plants. The experiment included 16 treatments resulted from combination of four rootstocks (i.e, Jumbo, Star, Felxi and Non-grafted ) were arranged in main plots and four foliar applications (i.e., salicylic acid at $200 \mathrm{mgL}^{-1}$, silicon at $100 \mathrm{mgL}^{-1}$, yeast at $10 \mathrm{gL}^{-1}$ and $\mathrm{Tap}$ water as a control) were arranged in sub plots The treatments were arranged in a randomized complete blocks design with three replicates. The results of the present study showed significant effects of rootstocks and different foliar applications on growth parameters and chemical characters of cucumber leaves and fruits. The results indicated that grafting on the different rootstocks and foliar applications treatments exerted significant effects on many growth aspects (i.e, survival rate, stem length, number of laterals branches, leaves area, fresh and dry weights of plants), fruit yield (total yield and early yield) and chemical characters of leaves and fruits the most effective treatment was obtained with grafting on Jumbo rootstock and spraying with yeast extract at $10 \mathrm{~g} / \mathrm{L}$ in both seasons of study. Since, it recorded the highest values of vegetative growth parameters, total and early yield with high nutritional value (i.e, N P K, TSS and Vitamin C) compared with other treatments during the two seasons.

Keywords: High tunnels cucumber; cucumber grafting, foliar application, yeast extract.

\section{INTRODUCTION}

Cucumber (Cucumis sativus L.) is regarded as one of the most popular vegetables in the world, and annually about 71.4 million tons are produced (FAO. Statistics.2015). In Egypt cucumber is used to produce under open field conditions and recently is considered as one of the main greenhouse cultivated vegetables. The total greenhouse area for cucumber production was 11.915 million square meters in 2014, and the production was 161 thousand ton in 2014. ( Ministry of Agriculture, 2015). Use of grafted seedlings became a widespread agricultural practice in many parts of the world and grafting is an important technique for vegetable production (Lee, 2003). The researchers consider that grafted plants, which provide increased yield and, consequently, higher profit, can be of value to farmers (Ruiz and Romero, 1999). Reported that grafting was enhanced the uptake of macronutrients such as phosphorus and nitrogen. Grafting is a recommended method for enhancing tolerance with some problems, including soil-borne diseases, soil nutrient imbalances, salty or alkaline soil conditions, spread of weeds, low temperature, etc.

In recent years, grafting has been found effective in overcoming a biotic stresses. A specific method of modifying plants to resist environmental stresses comprises grafting commercial cultivars onto selected vigorous rootstocks (Lee and Oda, 2003). Salicylic acid (SA) acts as an endogenous hormone like plant growth regulator, which has broad but different roles on stress adjustment and appears to be an effective agent for plant to overcome different stresses (Metwally et al., 2003 ; Vicente and Plasencia, 2011). Plants typically absorb bio-available silicon as a silicate -generally known as monosilicic or orthosilicic acid. Silicon (Si) is deposited as silica in the plant cell walls, improving cell wall structural rigidity and strength, plant architecture and leaf erectness (Epstein, 1994). It has been reported that Si applied by external foliar treatments or hydroponic supplementation has beneficial effects on plant growth and plays an important role in tolerance of plants to environmental stresses (Balakhnina and Borkowska, 2013; Rizwan et al.,2015 and Ma and Yamaji, 2006). several studies such as El- Ghamriny et al., 1999; Amer, 2004 and El-tohamy et al., 2008 reported that Bread yeast Saccharomyces cerevisiae is considered as a type of biostemulent which is usually used as foliar application on vegetable crops . Hence, The aim of this investigation was to improve the fruit yield and quality of the grafted cucumber plants grown under high polyethylene tunnels by using some foliar applications. i.e., such as yeast, silicon and salicylic acid.

\section{MATERIALS AND METHODS}

To achieve the goal of this study, two field experiments were established in winter seasons of 2014/2015 and 2015/2016 under high polyethylene tunnels in a private farm located in Belqas District, Dakahlia Governorate, Egypt. The investigation was aimed to study the effect of grafting onto different rootstocks and some foliar application on cucumber production under high polyethylene tunnels conditions The experiment included 16 treatments resulted from three rootstocks [i.e., Jumbo, Star, Felix which resulted from (Cucurbita maxima $\times$ Cucurbita moschata)] in addition non-grafted plants as a control were arranged in the main plots and four foliar applications (i.e., salicylic acid at $200 \mathrm{mgL}^{-1}$, silicon at $100 \mathrm{mgL}^{-1}$, yeast extract at $10 \mathrm{gL}^{-1}$ and tap water as a control were arranged in the sub plots. The treatments were arranged in a randomized complete blocks design with three replicates. Cleft plant grafting method was used according to Kubota et al. (2010). Surface soil samples were collected from (0-30 cm depth) and some physical and chemical properties of the studied soil are shown in Table 1 according to A O A C (1996)

Preparation of yeast extract was done according to El-Ghamriny et al. (1999). Salicylic acid (SA) was dissolved according to the method described by Williams et al. (2003). Silicon was dissolved according 
to the method described by Liang et al. (1994). Transplants of grafted and non-grafted cucumber plants were planted in high tunnels on $17^{\text {th }}$ and $20^{\text {th }}$ November in the first and second season of the study, respectively. The sub plot area was $10.5 \mathrm{~m}^{2}$ (i.e, $1.4 \mathrm{~m}$ width $\times 7.5 \mathrm{~m}$ length). At soil preparation, farmyard manure was applied at the rate of $2.25 \mathrm{~m}^{3} /$ high tunnel $\left(187.5 \mathrm{~m}^{2}\right)$ mixed with chemical fertilizers of $2 \mathrm{~kg}$ ammonium sulphate $(20.5 \% \mathrm{~N}), 10 \mathrm{Kg}$ calcium super phosphate $\left(12.5 \% \mathrm{p}_{2} \mathrm{O}_{5}\right)$ and $12.5 \mathrm{Kg}$ sulfur for each high tunnel. All agricultural practices for drip irrigation, fertilization and pesticide application were applied according to the Egyptian agriculture ministry recommendation.

Table 1. Some physical and chemical characteristics of soil during 2014-2015 and 2015-2016 seasons.

\begin{tabular}{|c|c|c|c|c|c|c|c|c|c|c|c|c|c|c|c|}
\hline \multirow{2}{*}{\multicolumn{2}{|c|}{$\begin{array}{l}\text { Soil } \\
\text { characteristics }\end{array}$}} & \multicolumn{2}{|c|}{ Sand (\%) } & \multirow{2}{*}{$\begin{array}{l}\text { Silt } \\
(\%)\end{array}$} & \multirow{2}{*}{$\begin{array}{l}\text { Clay } \\
(\%)\end{array}$} & \multirow{2}{*}{$\begin{array}{c}\mathrm{T} . \\
\text { class }\end{array}$} & \multirow{2}{*}{$\begin{array}{l}\text { F C } \\
(\%)\end{array}$} & \multirow{2}{*}{$\begin{array}{l}\text { Saturation } \\
\text { (\%) }\end{array}$} & \multirow{2}{*}{$\begin{array}{c}\mathrm{CaCo}_{3} \\
(\%)\end{array}$} & \multirow{2}{*}{$\begin{array}{l}\text { OM } \\
(\%)\end{array}$} & \multirow{2}{*}{ pH } & \multirow{2}{*}{$\begin{array}{c}\mathrm{EC} \\
\left(\mathrm{dSm}^{-1}\right)\end{array}$} & \multicolumn{3}{|c|}{ Available (mg/kg) } \\
\hline & & Coarse & Fine & & & & & & & & & & $\mathbf{N}$ & $\mathbf{P}$ & $\mathbf{K}$ \\
\hline \multirow{2}{*}{$\frac{\mathscr{d}}{\frac{0}{\sigma}}$} & $\begin{array}{l}\text { Season } 1 \\
(2014)\end{array}$ & 2.98 & 26.77 & 37.84 & 32.41 & \multirow{2}{*}{$\underset{U}{U}$} & 28.9 & 57.8 & 3.75 & 1.96 & 7.88 & 1.03 & 47.9 & 4.97 & 219.4 \\
\hline & $\begin{array}{c}\text { Season2 } \\
(2015)\end{array}$ & 3.76 & 25.61 & 38.47 & 32.16 & & 28.3 & 58.6 & 3.09 & 1.92 & 7.91 & 1.5 & 48.7 & 5.09 & 198.2 \\
\hline
\end{tabular}

Different morphological characteristics of cucumber plants at 30, 60 and 90 days from transplanting were measured and calculated. Five plants from each treatment were randomly chosen for determination.

The following characteristics were inspected:

1-Vegetative growth parameters :

- Survival \%: was determined at 30 days after transplanting.

- Stem length (cm) and Number of lateral branches: was determined at 90 days from transplanting.

- Leaf area $\left(\mathrm{cm}^{2}\right)$ was determined for the fifth leaf from apical bud at 60 days from transplanted.

- Fresh and dry weights (g/plant) were determined at 60 days from transplanting in the second season only.

2-Chemical constituents in leaves: (total chlorophyll $\mathrm{a}+\mathrm{b}$ content and N P K were determined in the dried leaves according A O A C (1996).

3-Fruit yield : early yield included the weight of fruits for all harvested fruits of the first 12 pickings $\left(\mathrm{kg} / \mathrm{m}^{2}\right)$, total yield included weight of fruits all over the harvesting season (36 pickings).

4-Fruit Chemical constituent and fruit quality characters: N P K \% , TSS, Vitamin C ( mg/100 g fw) according A O A C (1996).

The data were statistically analyzed according to Gomez and Gomez (1984).

\section{RESULTS AND DISCUSSION}

1-Effect of grafting and some foliar applications on vegetative growth characters :

Survival percentage:

Data in Table 2 illustrate that the plants grafted onto different rootstocks had a significant effect. The highest values of survival percentage was found at the tested rootstock 'Jumbo' followed with 'Star' then 'Felix' but the non-grafted plants recorded the lowest values Also, the individual effect of some foliar applications on survival percentage was recorded the highest values with yeast extract at $10 \mathrm{~g} / \mathrm{L}$ treatment followed by salicylic acid then silicon while Tap water (control) recorded the lowest values. The interaction effect between grafting and foliar application recorded the highest significant values when the tested rootstock Jumbo sprayed with yeast extract at $10 \mathrm{gL}-1$ while the lowest values were recorded when the non-grafting plants sprayed with tap water in both seasons of study.
The present results agree with those obtained by Abd-Alla (2002); Liu et al. (2012) and Rahmatian et al. (2014) who reported that graft compatibility between rootstock and scion is the most important factor influencing the survival of grafted plants. Also, many investigators reported that cucumber plants grafted onto cucurbita ficifolia gave the highest percentage of successful grafted plants. As the effect of foliar applications, Abou El-Yazied and Mady (2011)stated that foliar applications such as yeast increased survival percentage of cucumber and all growth parameters. It could be concluded that yeast as a natural source of cytokinins might enhance cell division and cell enlargement so far increasing the leaf surface area as well as enhancing the accumulation of soluble metabolites as mentioned about the role of cytokinins. Also, yeast is a natural source of Vitamin B and most of the essential elements. These results are in harmony with the finding of Said et al. (2012). Also the obtained positive effect of spraying salicylic (SA) acid on cucumber plants may be due to that SA is considered as a growth regulator which participates in the regulation of physiological processes in plants. Bhupinder and Usha (2003) stated that It stimulates flowering in a range of plants, increases flower life, controls ion uptake by roots and stomatal conductivity .

2-Stem length, number of lateral branches and leaf area :

Results presented in Table 2 show the effect of grafting onto different rootstocks and some foliar application and their interaction on vegetative growth parameters of cucumber plants. Generally grafting of cucumber plants had significantly increased vegetative growth parameters (i.e, stem length, number of lateral branches, and leaf area of the fifth leaf from the apical bud) as compared to the seedy plants (non-grafted).

The results proved that grafted cucumber plants onto Jumbo rootstock recorded the highest values of the previously mentioned growth parameters compared to the other rootstocks. While the grafting onto flexi fort recorded the lowest values. This trend is true for both seasons of the study.

Concerning the effect of some foliar application (i.e, yeast extract $10 \mathrm{~g} / \mathrm{L}$, salicylic acid $200 \mathrm{ppm} / \mathrm{L}$, silicon $100 \mathrm{ppm} / \mathrm{L}$ and tap water ( control)) on the vegetative growth parameters of cucumber plants, Its clear from the data presented in the same table that all foliar applications 
significantly recorded superior values compared to the control plant (tap water) meanwhile, the plants treated with yeast extract $10 \mathrm{~g} / \mathrm{L}$ recorded the highest values compared to the other foliar application treatments. While non significant differences were detected between salicylic acid and silicon treatments in this concern except in number of lateral branches in both seasons.

As regard to the interaction effect between grafting of cucumber plants and foliar application treatments on vegetative growth parameters, the obtained results declare that the interaction had a significant effect among the different treatments. The highest obtained values of vegetative growth parameters were obtained with grafted plants on Jumbo rootstock and sprayed with yeast extract at $10 \mathrm{~g} / \mathrm{L}$ in both seasons while the lowest ones were recorded with the control plants (seedy plants sprayed with tap water). The grafted plants on star rootstock sprayed with yeast extract at $10 \mathrm{~g} / \mathrm{L}$ came in the second order.

The present results are in agreement with those obtained by Abd-Alla (2002); Abou El-Yazeid (2011); Said et al. (2012) and Rahmatian et al. (2014).

Table 2. Effect of grafting onto different rootstocks and some foliar applications on survival percentage, stem length, number of lateral branches, leaf area* and their interactions of cucumber during 2014-2015 and 2015-2016 seasons.

\begin{tabular}{|c|c|c|c|c|c|c|c|c|c|}
\hline \multirow{2}{*}{\multicolumn{2}{|c|}{ Rootstocks }} & \multicolumn{2}{|c|}{$\begin{array}{c}\text { Survival \% at } \\
30 \text { days }\end{array}$} & \multicolumn{2}{|c|}{$\begin{array}{c}\text { Stem length }(\mathrm{cm}) \text { at } \\
90 \text { days }\end{array}$} & \multicolumn{2}{|c|}{$\begin{array}{c}\text { No.of lateral branches } \\
\text { at } 90 \text { days }\end{array}$} & \multicolumn{2}{|c|}{$\begin{array}{c}\text { Leaf area }\left(\mathrm{cm}^{2}\right) \text { at } \\
60 \text { days }\end{array}$} \\
\hline & & $2014 / 2015$ & $2015 / 2016$ & $2014 / 2015$ & $2015 / 2016$ & $2014 / 2015$ & $2015 / 2016$ & $2014 / 2015$ & $2015 / 2016$ \\
\hline \multicolumn{2}{|c|}{ Non-grafting } & 74.87 & 73.21 & 189.16 & 187.16 & 9.3 & 10.7 & 370.4 & 384.1 \\
\hline \multicolumn{2}{|l|}{ STAR } & 91.06 & 88.83 & 198.33 & 200.41 & 14.2 & 14.4 & 461.4 & 464.3 \\
\hline \multicolumn{2}{|l|}{ Jumbo } & 92.74 & 90.50 & 203.33 & 204.16 & 16.0 & 17.0 & 483.3 & 489.7 \\
\hline \multicolumn{2}{|l|}{ Felix } & 84.93 & 82.13 & 197.91 & 199.66 & 12.5 & 13.5 & 457.7 & 461.5 \\
\hline \multicolumn{2}{|l|}{$\mathrm{LSD}_{\text {at } 5 \%}$} & 3.40 & 7.42 & 3.40 & 1.69 & 0.5 & 0.9 & 13.2 & 11.7 \\
\hline & & & & Foliars & & & & & \\
\hline \multicolumn{2}{|c|}{ salicylic acid (200ppm) } & 86.04 & 81.57 & 197.50 & 197.75 & 12.3 & 13.0 & 444.4 & 449.5 \\
\hline \multicolumn{2}{|c|}{ Silicon (100ppm) } & 88.27 & 86.61 & 196.66 & 197.58 & 13.1 & 14.0 & 441.6 & 451.1 \\
\hline \multicolumn{2}{|c|}{ Yeast $(10 \mathrm{~g} / \mathrm{L})$} & 90.05 & 87.61 & 204.58 & 205.58 & 15.0 & 16.0 & 454.2 & 461.6 \\
\hline \multicolumn{2}{|c|}{ Tap water (control) } & 78.79 & 79.34 & 190.00 & 190.50 & 11.7 & 12.6 & 432.6 & 437.4 \\
\hline \multicolumn{2}{|l|}{$\mathrm{LSD}_{\text {at } 5 \%}$} & 5.02 & 6.93 & 3.06 & 2.20 & 0.3 & 0.4 & 3.3 & 4.1 \\
\hline \multicolumn{10}{|c|}{ Interaction } \\
\hline \multirow{4}{*}{$\begin{array}{l}\text { Non- } \\
\text { grafting }\end{array}$} & salicylic acid (200ppm) & 77.66 & 75.43 & 190.00 & 189.00 & 9.3 & 10.6 & 372.4 & 381.3 \\
\hline & Silicon (100ppm) & 77.66 & 75.43 & 186.66 & 187.66 & 9.3 & 11.0 & 370.7 & 387.4 \\
\hline & Yeast $(10 \mathrm{~g} / \mathrm{L})$ & 77.66 & 71.03 & 198.33 & 199.00 & 10.0 & 12.0 & 378.4 & 398.0 \\
\hline & Tap water (control) & 66.50 & 70.96 & 181.66 & 173.00 & 8.6 & 9.3 & 360.0 & 370.0 \\
\hline \multirow{4}{*}{ Star } & salicylic acid (200ppm) & 77.66 & 84.36 & 198.33 & 199.33 & 13.0 & 12.6 & 462.1 & 464.8 \\
\hline & Silicon (100ppm) & 93.30 & 93.30 & 198.33 & 199.33 & 14.0 & 14.0 & 463.1 & 466.3 \\
\hline & Yeast $(10 \mathrm{~g} / \mathrm{L})$ & 93.30 & 93.30 & 205.00 & 207.33 & 16.6 & 17.6 & 467.8 & 470.6 \\
\hline & Tap water (control) & 88.60 & 84.36 & 191.66 & 195.66 & 13.3 & 14.3 & 452.7 & 455.6 \\
\hline \multirow{4}{*}{ Jumbo } & salicylic acid (200ppm) & 91.06 & 91.06 & 203.33 & 203.33 & 15.0 & 16.0 & 482.2 & 486.8 \\
\hline & Silicon (100ppm) & 91.06 & 91.06 & 203.33 & 204.00 & 16.3 & 17.3 & 476.5 & 490.0 \\
\hline & Yeast $(10 \mathrm{~g} / \mathrm{L})$ & 97.76 & 95.53 & 210.00 & 210.33 & 19.0 & 20.0 & 504.3 & 506.7 \\
\hline & Tap water (control) & 91.06 & 84.36 & 196.66 & 199.00 & 14.0 & 15.0 & 470.2 & 475.3 \\
\hline \multirow{4}{*}{ Flexi fort } & salicylic acid (200ppm) & 84.36 & 75.43 & 198.33 & 199.33 & 12.0 & 13.0 & 461.0 & 465.3 \\
\hline & Silicon (100ppm) & 91.06 & 88.83 & 198.33 & 199.33 & 13.0 & 14.0 & 456.0 & 460.8 \\
\hline & Yeast $(10 \mathrm{~g} / \mathrm{L})$ & 93.30 & 86.60 & 205.00 & 205.66 & 14.3 & 15.3 & 466.3 & 471.3 \\
\hline & Tap water (control) & 71.00 & 77.66 & 190.00 & 194.33 & 11.0 & 12.0 & 447.6 & 484.8 \\
\hline \multicolumn{2}{|l|}{$\mathrm{LSD}_{\text {at } 5 \%}$} & 10.04 & 13.86 & 6.12 & 4.41 & 0.7 & 0.8 & 6.7 & 8.2 \\
\hline
\end{tabular}

\section{3- Plant fresh and dry weight.}

Data of Table 3 show that the plants grafted onto different rootstocks had the highest significant values of fresh and dry weights compared to non grafted (control) .and the tested rootstock 'Jumbo' recorded the highest values of fresh and dry weights during the second season of study but the non-grafted recorded the lowest values

Also data show the individual effect of some foliar applications on fresh and dry weight and indicated that the yeast extract at $10 \mathrm{~g} / \mathrm{L}$ recorded the highest values of the fresh and dry weight as compared with other treatments in this respect. Salicylic acid treatment came in the second order then silicon treatment. The interaction between grafting on different rootstocks and foliar applications recorded the highest significant values when the tested rootstock Jumbo sprayed with yeast extract at $10 \mathrm{gL}-1$.while, the lowest values were recorded when the non-grafted plants sprayed with tap water in both seasons of study.

The present results are in agreement with those obtained by Abd-Alla (2002) who grafted cucumber plants Nile cv. onto squash, pumpkins (Cucurbita moschata), pumpkin (C. maxima), bottle gourd, fig leaf gourd and non-grafted cucumber and found that the plants grafted onto fig leaf gourd and bottle gourd had the highest values of fresh and dry weights of leaves compared with the other used rootstocks or the nongrafted ones. Also, when Huaifu et al. (2006) investigated the growth of cucumber (Cucumis sativus) grafted on smooth luffa (Luffa cylindrica L.) compared with self-rooted plants they found that cucumber grafted on smooth luffa showed significantly higher values for 
the fresh and dry mass of grafted seedlings compared to non-grafted plants.

Table 3. Effect of grafting onto different rootstocks and some foliar applications on fresh and dry weight and their interactions of cucumber plants during 2015-2016 season .

\begin{tabular}{|c|c|c|c|}
\hline \multicolumn{2}{|r|}{ Characters } & $\begin{array}{c}\begin{array}{c}\text { Fresh weight } \\
\text { g/plant }\end{array} \\
\mathbf{2 0 1 5} / 2016 \\
\end{array}$ & $\begin{array}{c}\begin{array}{c}\text { Dry weight } \\
\text { g/plant }\end{array} \\
2015 / 2016 \\
\end{array}$ \\
\hline \multicolumn{2}{|c|}{ Non-grafting } & 1510.3 & 170.1 \\
\hline \multicolumn{2}{|c|}{ STAR } & 1552.7 & 189.6 \\
\hline \multicolumn{2}{|l|}{ Jumbo } & 1577.0 & 202.5 \\
\hline \multicolumn{2}{|l|}{ Felix } & 1544.8 & 185.7 \\
\hline \multicolumn{2}{|l|}{$\mathrm{LSD}_{\text {at } 5 \%}$} & 4.1 & 3.6 \\
\hline \multicolumn{4}{|c|}{ Foliars } \\
\hline \multicolumn{2}{|c|}{ salicylic acid (200ppm) } & 1561.8 & 189.6 \\
\hline \multicolumn{2}{|c|}{ Silicon (100ppm) } & 1543.5 & 186.0 \\
\hline \multicolumn{2}{|c|}{ Yeast $(10 \mathrm{~g} / \mathrm{L})$} & 1580.8 & 196.0 \\
\hline \multicolumn{2}{|c|}{ Tap water (control) } & 1498.6 & 176.3 \\
\hline \multicolumn{2}{|l|}{$\underline{\mathrm{LSD}_{\text {at }} 5 \%}$} & 3.7 & 1.8 \\
\hline \multicolumn{4}{|c|}{ Interactions } \\
\hline \multirow{4}{*}{$\begin{array}{l}\text { Non- } \\
\text { grafting }\end{array}$} & salicylic acid (200ppm) & 1530.3 & 172.3 \\
\hline & Silicon (100ppm) & 1510.2 & 170.3 \\
\hline & Yeast $(10 \mathrm{~g} / \mathrm{L})$ & 1540.5 & 177.1 \\
\hline & Tap water (control) & 1460.2 & 161.0 \\
\hline \multirow{4}{*}{ Star } & salicylic acid (200ppm) & 1566.4 & 192.4 \\
\hline & Silicon (100ppm) & 1546.9 & 190.6 \\
\hline & Yeast $(10 \mathrm{~g} / \mathrm{L})$ & 1588.2 & 197.4 \\
\hline & Tap water (control) & 1509.3 & 178.1 \\
\hline \multirow{4}{*}{ Jumbo } & salicylic acid (200ppm) & 1590.5 & 205.5 \\
\hline & Silicon (100ppm) & 1576.6 & 196.0 \\
\hline & Yeast $(10 \mathrm{~g} / \mathrm{L})$ & 1621.1 & 216.2 \\
\hline & Tap water (control) & 1520.1 & 192.3 \\
\hline \multirow{4}{*}{ Flexi fort } & salicylic acid (200ppm) & 1560.2 & 188.4 \\
\hline & Silicon (100ppm) & 1540.4 & 187.2 \\
\hline & Yeast $(10 \mathrm{~g} / \mathrm{L})$ & 1573.4 & 193.3 \\
\hline & Tap water (control) & 1505.1 & 174.1 \\
\hline $\mathrm{LSD}_{\text {at } 5 \%}$ & & 7.4 & 3.7 \\
\hline
\end{tabular}

\section{2- Effect of grafting and some foliar applications on} chemical content of leaves:

Results presented in Table 4 show the effect of grafting onto different rootstocks and some foliar application and their interactions on $\mathrm{N}, \mathrm{P}$, and $\mathrm{K}$ percentages and total Chlorophyll in cucumber leaves. Generally grafting of cucumber plants had significantly increased $\mathrm{N}$ and $\mathrm{K}$ percentages on leaves as compared to the seedy plants (non-grafted). But there is insignificant effect was found in P percentages in both seasons of study. The grafted plants onto Jumbo rootstock gave the highest total Chlorophyll in the both seasons. In the contrary, nongrafted plants and grafted plants onto 'Star ' rootstock showed the lowest values in both seasons without significance between both treatments.

The results proved that grafted cucumber plants onto Jumbo rootstock recorded the highest values of the $\mathrm{N}$ and $\mathrm{K}$ percentages in leaves compared to the other rootstocks. While the grafting onto flexi fort recorded the lowest values .this trend is true for both seasons of the study.

Concerning the effect of some foliar application (i.e., yeast extract $10 \mathrm{~g} / \mathrm{L}$, salicylic acid $200 \mathrm{ppm} / \mathrm{L}$, silicon $100 \mathrm{ppm} / \mathrm{L}$ and Tap water ( control)) on N, P, and $\mathrm{K}$ percentages and total Chlorophyll of cucumber leaves, its clear from the data presented in the same table that all foliar applications significantly recorded superior values compared to the control plant (tap water) meanwhile the plants treated with yeast extract $10 \mathrm{~g} / \mathrm{L}$ recorded the highest values compared to the other foliar application treatments. While non significant differences were detected in $\mathrm{P}$ concentration percentage in leaves in both seasons.

As regard to the interaction effect between grafting of cucumber plants and foliar application treatments on the previous characters, the obtained results declare that the interaction had a significant effect among the different treatments. The highest obtained values of N P K parameters were obtained with grafted plants on Jumbo rootstock and sprayed with yeast extract at $10 \mathrm{~g} / \mathrm{L}$ in both seasons and the grafted plants on star rootstock sprayed with yeast extract at $10 \mathrm{~g} / \mathrm{L}$ came in the second order. While the lowest ones were recorded with the control plants (seedy plants sprayed with tap water).

These results are supported by the findings of Mohamed et al. (2014) who suggested that superior results of grafting may be due to promote the movement of water and nutrients from rootstock to scion as a result of the better development of vascular bundles which depends on the good adhesion between rootstock and scion.

The positive obtained results of grafting on vegetative growth parameters, N.P.K percentages and total chlorophyll may be due to that the grafted plants have a vigor root system which be influences absorption and translocation of mineral nutrients and increase photosynthesis (Ikeda et al., 1986; Kim and Lee, 1989; Ruiz et al., 1997; Pulgar et al., 2000; Hu et al., 2005) and The positive effects of foliar applications like yeast extract refers to its content of natural vitamins cytokinins, enzymes, amino acids and minerals (Khedr and Farid, 2002; Mahmoud, 2001). It was reported that, dry yeast has stimulatory effects on cell division and enlargement, protein and nucleic acid synthesis and Chlorophyll formation (Kraig and Haber, 1980; Castelfranco and Beale, 1983). It participates in a beneficial role during stress due to its content of cytokinins (Barnett et al.,1990). Improving growth and productivity of vegetable crops by application of active yeast extract were recorded by several studies such as on beans (Fathy and Farid, 1996; Amer, 2004 ; ElTohamy and El-Greadly, 2008).

Also, many studies showed that Salicylic Acid (SA) is an essential component in the signal transduction pathway leading to systemic acquired resistance (Meuwly et al., 1995). And (SA) is a growth regulator which participates in the regulation of many physiological processes in plants. It stimulates flowering in a range of plants, increases flower life, controls ion uptake by roots and stomatal conductivity (Bhupinder and Usha, 2003).

Numerous greenhouse, laboratory and field experiments have demonstrated that $\mathrm{Si}$ is able to hamper both biotic pressures caused by pest attacks and plant diseases, as well as a biotic pressures, including physical pressures such as water logging, drought, high temperature, freezing, UV, and chemical pressures as nutrient deficiencies, salinity, and metal toxicity ( Guntzer et al., 2012; Balakhnina and Borkowska, 2013; Marafon and Endres, 2013; Jonas et al., 2013; Zhu and 
Gong, 2014; Rizwan et al.,2015) . And the significant role of Silicon that $\mathrm{Si}$ deposited on the tissue surface acts as a physical barrier. It prevents physical penetration and protects plants from temperature stresses and makes the plant cells less susceptible to enzymatic degradation by fungal pathogens. This mechanism is supported by the positive correlation between degree of suppression of pests and diseases and Si content Cherif et al. (1994).

Table 4. Effect of grafting onto different rootstocks and some foliar applications on Nitrogen, phosphorus and potassium percentages and total chlorophyll $(\mathrm{mg} / \mathrm{g} \mathrm{FW})$, and their interactions of cucumber leaves during 2014-2015 and 2015-2016 seasons:

\begin{tabular}{|c|c|c|c|c|c|c|c|c|c|}
\hline \multirow[b]{2}{*}{ Rootstocks } & \multirow[t]{2}{*}{ Characters } & \multicolumn{2}{|c|}{ N \% } & \multicolumn{2}{|c|}{$\mathbf{P \%}$} & \multicolumn{2}{|c|}{$\mathbf{K} \%$} & \multicolumn{2}{|c|}{$\begin{array}{c}\text { Total Chlorophyll } \\
\text { mg/g FW }\end{array}$} \\
\hline & & 2014/2015 & 2015/2016 & $62014 / 2015$ & $52015 / 2016$ & $62014 / 2015$ & $2015 / 2016$ & $2014 / 2015$ & $2015 / 2016$ \\
\hline \multicolumn{2}{|l|}{ Non-grafting } & 3.50 & 3.43 & 0.355 & 0.311 & 2.64 & 2.94 & 1.046 & 1.045 \\
\hline \multicolumn{2}{|l|}{ STAR } & 3.34 & 3.26 & 0.338 & 0.294 & 2.48 & 2.77 & 0.995 & 0.999 \\
\hline \multicolumn{2}{|l|}{ Jumbo } & 3.55 & 3.54 & 0.363 & 0.322 & 2.69 & 3.03 & 1.062 & 1.064 \\
\hline \multicolumn{2}{|l|}{ Felix } & 3.42 & 3.33 & 0.347 & 0.302 & 2.56 & 3.02 & 1.028 & 1.030 \\
\hline \multicolumn{2}{|l|}{$\mathrm{LSD}_{\text {at } 5 \%}$} & 0.02 & 0.05 & 0.001 & 0.005 & 0.03 & 0.15 & 0.015 & 0.017 \\
\hline \multicolumn{10}{|c|}{ Foliars } \\
\hline \multicolumn{2}{|c|}{ salicylic acid (200ppm) } & 3.64 & 3.57 & 0.365 & 0.327 & 2.74 & 3.07 & 1.072 & 1.075 \\
\hline \multicolumn{2}{|c|}{ Silicon (100ppm) } & 3.31 & 3.21 & 0.335 & 0.288 & 2.45 & 2.72 & 1.002 & 1.005 \\
\hline \multicolumn{2}{|c|}{ Yeast $(10 \mathrm{~g} / \mathrm{L})$} & 3.87 & 3.93 & 0.401 & 0.362 & 3.01 & 3.44 & 1.123 & 1.125 \\
\hline \multicolumn{2}{|c|}{ Tap water (control) } & 3.00 & 2.84 & 0.302 & 0.252 & 2.17 & 2.53 & 0.933 & 0.936 \\
\hline \multicolumn{2}{|c|}{$\mathrm{LSD}_{\text {at }} \%$} & 0.02 & 0.03 & 0.003 & 0.002 & 0.03 & 0.11 & 0.013 & 0.013 \\
\hline \multicolumn{10}{|c|}{ Interaction } \\
\hline \multirow{4}{*}{ Non-grafting } & salicylic acid (200ppm) & 3.71 & 3.60 & 0.381 & 0.332 & 2.79 & 3.11 & 1.081 & 1.083 \\
\hline & Silicon (100ppm) & 3.34 & 3.25 & 0.340 & 0.290 & 2.49 & 2.76 & 1.011 & 1.013 \\
\hline & Yeast $(10 \mathrm{~g} / \mathrm{L})$ & 3.92 & 3.97 & 0.406 & 0.368 & 3.07 & 3.49 & 1.148 & 1.151 \\
\hline & Tap water (control) & 3.05 & 2.89 & 0.307 & 0.256 & 2.20 & 2.42 & 0.941 & 0.944 \\
\hline \multirow{4}{*}{ Star } & salicylic acid (200ppm) & 3.52 & 3.43 & 0.353 & 0.314 & 2.63 & 2.96 & 1.048 & 1.050 \\
\hline & Silicon (100ppm) & 3.17 & 3.09 & 0.322 & 0.275 & 2.34 & 2.58 & 0.975 & 0.978 \\
\hline & Yeast $(10 \mathrm{~g} / \mathrm{L})$ & 3.78 & 3.80 & 0.388 & 0.348 & 2.90 & 3.31 & 1.049 & 1.051 \\
\hline & Tap water (control) & 2.89 & 2.71 & 0.289 & 0.238 & 2.08 & 2.23 & 0.907 & 0.909 \\
\hline \multirow{4}{*}{ Jumbo } & salicylic acid (200ppm) & 3.70 & 3.73 & 0.342 & 0.342 & 2.83 & 3.19 & 1.098 & 1.098 \\
\hline & Silicon (100ppm) & 3.44 & 3.37 & 0.345 & 0.306 & 2.56 & 2.87 & 1.029 & 1.031 \\
\hline & Yeast $(10 \mathrm{~g} / \mathrm{L})$ & 3.96 & 4.08 & 0.412 & 0.375 & 3.12 & 3.59 & 1.163 & 1.165 \\
\hline & Tap water (control) & 3.12 & 2.98 & 0.313 & 0.264 & 2.26 & 2.49 & 0.958 & 0.960 \\
\hline \multirow{4}{*}{ Flexi fort } & salicylic acid (200ppm) & 3.63 & 3.52 & 0.360 & 0.319 & 2.72 & 3.04 & 1.062 & 1.065 \\
\hline & Silicon (100ppm) & 3.29 & 3.14 & 0.332 & 0.283 & 2.43 & 2.68 & 0.992 & 0.995 \\
\hline & Yeast $(10 \mathrm{~g} / \mathrm{L})$ & 3.82 & 3.87 & 0.399 & 0.357 & 2.96 & 3.39 & 1.132 & 1.135 \\
\hline & Tap water (control) & 2.95 & 2.79 & 0.298 & 0.249 & 2.15 & 2.98 & 0.925 & 0.930 \\
\hline $\mathrm{LSD}_{\text {at } 5 \%}$ & & 0.05 & 0.06 & N.S & N.S & 0.06 & 0.23 & 0.027 & 0.029 \\
\hline
\end{tabular}

\section{3- Effect of grafting and some foliar applications on cucumber fruit yield:}

Results presented in Table 5 show the effect of grafting onto different rootstocks and some foliar application and their interaction on fruit yield of cucumber plants. Generally grafting of cucumber plants had significantly increased fruit yield parameters (early and total yield) as compared to the seedy plants (nongrafted).The results proved that grafted cucumber plants onto Jumbo rootstock recorded the highest values of the fruit yield compared to the other rootstocks. While the grafting onto flexi fort recorded the lowest values .this trend is true for both seasons of the study.

Concerning the effect of some foliar application (i.e., yeast extract $10 \mathrm{~g} / \mathrm{L}$, salicylic acid $200 \mathrm{ppm} / \mathrm{L}$, silicon $100 \mathrm{ppm} / \mathrm{L}$ and Tap water ( control)) on the fruit yield of cucumber plants, its clear from the data presented in the same table that all foliar applications significantly recorded superior values compared to the control plant sprayed with (tap water) meanwhile the plants treated with yeast extract $10 \mathrm{~g} / \mathrm{L}$ recorded the highest values compared to the other foliar applications treatments.
As regard to the interaction effect between grafting of cucumber plants and foliar application treatments on fruit yield, the obtained results declare that the interaction had a significant effect among the different treatments. The highest obtained values of fruit yield were obtained with grafted plants on Jumbo rootstock and sprayed with yeast extract at $10 \mathrm{~g} / \mathrm{L}$ in both seasons and the grafted plants on star rootstock sprayed with yeast extract at $10 \mathrm{~g} / \mathrm{L}$ came in the second order. While the lowest ones were recorded with the control plants (seedy plants sprayed with tap water).

In our study, the increase of cucumber fruit yield due to grafting and foliar application might be attributed to the increase of vegetative growth parameters (table 2) , high $\mathrm{N}, \mathrm{P}, \mathrm{K}$ percentage in leaves and chlorophyll content table 4 , which enhanced photosynthesis efficiency and that is a good explain for increasing plant growth and dry matter production as shown in table 3 this enhancement could be an indicator for expectable high yield fruits and higher N,P,K concentration in the fruits. 
Table 5. Effect of grafting onto different rootstocks and some foliar applications on early, total yield, and their interactions of cucumber during 2014-2015 and 2015-2016 seasons.

\begin{tabular}{|c|c|c|c|c|c|}
\hline \multirow[b]{2}{*}{ Rootstocks } & \multirow[t]{2}{*}{ Characters } & \multicolumn{2}{|c|}{ Early yield $\mathrm{Kg} / \mathrm{m}^{2}$} & \multicolumn{2}{|c|}{ Total yield $\mathrm{Kg} / \mathrm{m}^{2}$} \\
\hline & & $2014 / 2015$ & $2015 / 2016$ & $2014 / 2015$ & $2015 / 2016$ \\
\hline$\overline{\text { Non-grafting }}$ & & 3.41 & 3.58 & 8.09 & 8.38 \\
\hline STAR & & 4.67 & 4.87 & 11.02 & 11.36 \\
\hline Jumbo & & 4.96 & 5.17 & 13.76 & 13.98 \\
\hline Felix & & 4.25 & 4.45 & 10.29 & 10.62 \\
\hline $\mathrm{LSD}_{\text {at } 5 \%}$ & & 0.14 & 0.15 & 0.17 & 0.18 \\
\hline \multicolumn{6}{|c|}{ Foliars } \\
\hline$\overline{\text { salicylic acid }}$ & & 4.25 & 4.44 & 10.28 & 10.63 \\
\hline Silicon $(100$ & & 4.37 & 4.75 & 11.15 & 11.43 \\
\hline Yeast $(10 \mathrm{~g} /$ & & 4.67 & 4.88 & 11.91 & 12.13 \\
\hline Tap water (c & & 3.98 & 4.17 & 9.82 & 10.13 \\
\hline $\mathrm{LSD}_{\text {at } 5 \%}$ & & 0.08 & 0.08 & 0.10 & 0.15 \\
\hline \multicolumn{6}{|c|}{ Interactions } \\
\hline \multirow{4}{*}{ Non-grafting } & salicylic acid (200ppm) & 3.34 & 3.51 & 7.70 & 7.99 \\
\hline & Silicon (100ppm) & 3.50 & 3.67 & 8.41 & 8.69 \\
\hline & Yeast $(10 \mathrm{~g} / \mathrm{L})$ & 3.65 & 3.83 & 8.88 & 9.17 \\
\hline & Tap water (control) & 3.15 & 3.32 & 7.39 & 7.67 \\
\hline \multirow{4}{*}{ Star } & salicylic acid (200ppm) & 4.64 & 4.85 & 10.60 & 11.13 \\
\hline & Silicon (100ppm) & 4.58 & 4.79 & 11.13 & 11.42 \\
\hline & Yeast $(10 \mathrm{~g} / \mathrm{L})$ & 5.05 & 5.26 & 12.12 & 12.41 \\
\hline & Tap water (control) & 4.40 & 4.60 & 10.25 & 10.47 \\
\hline \multirow{4}{*}{ Jumbo } & salicylic acid (200ppm) & 4.83 & 5.01 & 13.10 & 13.39 \\
\hline & Silicon (100ppm) & 5.08 & 5.29 & 14.41 & 14.69 \\
\hline & Yeast $(10 \mathrm{~g} / \mathrm{L})$ & 5.51 & 5.74 & 15.10 & 15.07 \\
\hline & Tap water (control) & 4.43 & 4.63 & 12.44 & 12.79 \\
\hline \multirow{4}{*}{ Flexi fort } & salicylic acid (200ppm) & 4.21 & 4.41 & 9.74 & 10.03 \\
\hline & Silicon (100ppm) & 4.33 & 4.53 & 10.66 & 10.94 \\
\hline & Yeast $(10 \mathrm{~g} / \mathrm{L})$ & 4.49 & 4.69 & 11.55 & 11.89 \\
\hline & Tap water (control) & 3.96 & 4.15 & 9.23 & 9.61 \\
\hline $\mathrm{LSD}_{\text {at } 5 \%}$ & & 0.17 & 0.17 & 0.20 & 0.31 \\
\hline
\end{tabular}

In this concern, many authors proved that grafting affected fruit yield of cucumber Mady (2009). Besides, El-Sayed et al., (2014) who stated that grafting increased early and total yield of cucumber fruits. Also, these results are supported by the findings of Barnett et al. (1990). Besides Said et al. (2012) suggested that superior results of Yeast extract treatments to participate a beneficial role during stress due to its auxins, cytokinins and gibberellins content while improve the formation of flower initiation due to its effect on accumulation of carbohydrates.

5- Effect of grafting and some foliar applications on N.P.K percentage and fruit quality parameters:

Results presented in Table 6 show the effect of grafting onto different rootstocks and some foliar applications and their interaction on $\mathrm{N}, \mathrm{P}$, and $\mathrm{K}$ percentages in fruits, TSS and vitamin $\mathrm{C}$ of cucumber fruits. Generally grafting of cucumber plants had significantly increased $\mathrm{N}$ and $\mathrm{K}$ concentration percentages in fruits as compared to the seedy plants (non-grafted). But there is no significant effect on $\mathrm{P}$ percentage in the both seasons of study. For TSS, The results in the same table show that the greatest values of TSS were recorded by grafting onto the tested rootstock Jumbo, while grafted plants onto Star rootstock gave the lowest values in both seasons. Furthermore, the obtained results indicate that vitamin $\mathrm{C}$ was significantly influenced by grafting. Since, the greatest vitamin $\mathrm{C}$ values were observed in grafted cucumber onto Jumbo rootstock, while grafted plants onto Star rootstock gave the lowest values in both seasons.

Concerning the effect of some foliar application (i.e., yeast extract $10 \mathrm{~g} / \mathrm{L}$, salicylic acid $200 \mathrm{ppm} / \mathrm{L}$, silicon $100 \mathrm{ppm} / \mathrm{L}$ and tap water ( control)) on N, P, and $\mathrm{K}$ percentages, TSS and vitamin $\mathrm{C}$ of cucumber fruits, its clear from the data presented in the same table that all foliar applications significantly recorded superior values compared to the control plant (tap water) meanwhile the plants treated with yeast extract at $10 \mathrm{~g} / \mathrm{L}$ recorded the highest values compared to the other foliar application treatments. While non significant differences were detected in $\mathrm{P}$ percentage in fruits in both seasons.

As regard to the interaction effect between grafting of cucumber plants and foliar application treatments on the previous mentioned treats, the obtained results declare that the interaction had significant effects among the different treatments. The highest obtained values of previously mentioned treats were associated with grafted plants on Jumbo rootstock and sprayed with yeast extract at $10 \mathrm{~g} / \mathrm{L}$ in both seasons and the grafted plants on star rootstock sprayed with yeast extract at $10 \mathrm{~g} / \mathrm{L}$ came in the second order. While the lowest ones were recorded with the control plants (seedy plants sprayed with tap water. But there is insignificant effect on $\mathrm{P}$ percentage in the both seasons of study. 
The present results agree with those obtained by Abd-Alla (2002) and El-Semellawy (2005). Who found that grafting cucumber onto pumpkin or squash led to raise TSS\% of fruits. On the contrary, Hongli et al., (2003) recorded negative effect for grafting, where contents of soluble sugar, vitamin C, amino acids particularly, glutamic and aspartic acids decreased and the contents of nitrate, tannititrable acid increased in the grafted cucumber on figleaf gourd (Cucurbit cificifolia) and Sintozwa (Cucurbita maxima $x$ C.' moschata). Other studies suggested that grafting (rootstock) has insignificant effects on fruit dry matter and soluble sugar content of cucumber under unstressed conditions Zhu et al. (2006); Zhong and Bie (2007).

Table 6. Effect of grafting onto different rootstocks and some foliar applications on the percentage of Nitrogen, phosphorus and potassium percentage, TSS percentage and Vitamin .C (mg/100g) and their interactions of cucumber fruit during 2014-2015 and 2015-2016 seasons.

\begin{tabular}{|c|c|c|c|c|c|c|c|c|c|c|}
\hline \multirow{2}{*}{ Rootstocks } & \multicolumn{2}{|c|}{ N\% } & \multicolumn{2}{|c|}{$\mathbf{P \%}$} & \multicolumn{2}{|c|}{ K\% } & \multicolumn{2}{|c|}{ V.C mg/100g F.W } & \multicolumn{2}{|c|}{ TSS\% } \\
\hline & $\begin{array}{l}2014 / \\
2015\end{array}$ & $\begin{array}{l}2015 / \\
2016\end{array}$ & $\begin{array}{l}2014 / \\
2015\end{array}$ & $\begin{array}{c}2015 / \\
2016\end{array}$ & $\begin{array}{l}2014 / \\
2015\end{array}$ & $\begin{array}{l}2015 / \\
2016\end{array}$ & $\begin{array}{l}2014 / \\
2015 \\
\end{array}$ & $\begin{array}{l}2015 / \\
2016\end{array}$ & $\begin{array}{l}2014 / \\
2015\end{array}$ & $\begin{array}{c}2015 / \\
2016 \\
\end{array}$ \\
\hline Non-grafting & 1.58 & 1.97 & 0.242 & 0.243 & 1.56 & 2.08 & 3.197 & 3.195 & 5.10 & 5.20 \\
\hline STAR & 1.48 & 1.79 & 0.231 & 0.227 & 1.44 & 1.89 & 3.091 & 3.090 & 4.91 & 4.95 \\
\hline Jumbo & 1.62 & 2.06 & 0.249 & 0.253 & 1.63 & 2.15 & 3.263 & 3.260 & 5.19 & 5.209 \\
\hline Felix & 1.53 & 1.98 & 0.241 & 0.236 & 1.49 & 1.97 & 3.145 & 3.140 & 4.97 & 4.99 \\
\hline $\mathrm{LSD}_{\text {at } 5 \%}$ & 0.04 & 0.14 & 0.009 & 0.003 & 0.04 & 0.02 & 0.05 & 0.045 & 0.02 & 0.02 \\
\hline \multicolumn{11}{|c|}{ Foliars } \\
\hline salicylic acid (200ppm) & 1.66 & 2.11 & 0.253 & 0.257 & 1.67 & 2.19 & 3.268 & 3.265 & 5.24 & 5.28 \\
\hline Silicon (100ppm) & 1.46 & 1.75 & 0.229 & 0.222 & 1.39 & 1.85 & 3.058 & 3.055 & 4.85 & 4.89 \\
\hline Yeast $(10 \mathrm{~g} / \mathrm{L})$ & 1.84 & 2.46 & 0.280 & 0.294 & 1.93 & 2.55 & 3.495 & 3.490 & 5.64 & 5.69 \\
\hline Tap water (control) & 1.24 & 1.47 & 0.200 & 0.186 & 1.13 & 1.51 & 2.875 & 2.870 & 4.44 & 4.49 \\
\hline $\mathrm{LSD}_{\text {at } 5 \%}$ & 0.04 & 0.12 & 0.006 & 0.002 & 0.03 & 0.03 & 0.055 & 0.050 & 0.02 & 0.02 \\
\hline \multicolumn{11}{|c|}{ Interaction } \\
\hline \multirow{4}{*}{$\begin{array}{lc}\text { Non- } & \text { Salicylic acid }(200 \mathrm{ppm}) \\
\text { grafted } & \text { Silicon }(100 \mathrm{ppm}) \\
& \text { Yeast }(10 \mathrm{~g} / \mathrm{L}) \\
& \text { Tap water (control) } \\
\end{array}$} & 1.69 & 2.15 & 0.250 & 0.261 & 1.69 & 2.23 & 3.287 & 3.285 & 5.28 & 5.30 \\
\hline & 1.48 & 1.78 & 0.231 & 0.225 & 1.43 & 1.90 & 3.090 & 3.08 & 4.90 & 4.95 \\
\hline & 1.88 & 2.51 & 0.283 & 0.299 & 1.97 & 2.32 & 3.520 & 3.510 & 5.70 & 5.75 \\
\hline & 1.27 & 1.43 & 0.203 & 0.189 & 1.15 & 1.57 & 2.890 & 2.888 & 4.52 & 4.55 \\
\hline salicylic acid (200ppm) & 1.59 & 1.98 & 0.249 & 0.243 & 1.56 & 2.07 & 3.180 & 3.175 & 5.11 & 5.16 \\
\hline Silicon (100ppm) & 1.39 & 1.62 & 0.214 & 0.210 & 1.31 & 1.71 & 2.983 & 2.980 & 4.72 & 4.77 \\
\hline Yeast $(10 \mathrm{~g} / \mathrm{L})$ & 1.78 & 2.32 & 0.271 & 0.282 & 1.86 & 2.42 & 3.407 & 3.405 & 5.48 & 5.51 \\
\hline Tap water (control) & 1.24 & 1.24 & 0.190 & 0.173 & 1.03 & 1.38 & 2.793 & 2.790 & 4.31 & 4.35 \\
\hline salicylic acid (200ppm) & 1.74 & 2.24 & 0.262 & 0.270 & 1.78 & 2.32 & 3.347 & 3.342 & 5.38 & 5.40 \\
\hline Jumbo Silicon (100ppm) & 1.53 & 1.89 & 0.239 & 0.236 & 1.50 & 1.98 & 3.127 & 3.125 & 4.99 & 5.10 \\
\hline Yeast $(10 \mathrm{~g} / \mathrm{L})$ & 1.89 & 2.59 & 0.287 & 0.308 & 2.02 & 2.68 & 3.597 & 3.595 & 5.80 & 5.90 \\
\hline Tap water (control) & 1.32 & 1.52 & 0.210 & 0.200 & 1.23 & 1.63 & 2.980 & 2.975 & 4.60 & 4.65 \\
\hline Flexi $\quad$ salicylic acid (200ppm) & 1.63 & 2.08 & 0.252 & 0.256 & 1.64 & 2.13 & 3.257 & 3.255 & 5.17 & 5.20 \\
\hline \multirow{4}{*}{ 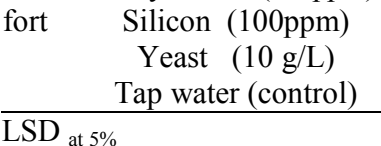 } & 1.17 & 1.72 & 0.234 & 0.217 & 1.34 & 1.81 & 3.030 & 3.02 & 4.79 & 4.81 \\
\hline & 1.83 & 2.42 & 0.281 & 0.289 & 1.89 & 2.49 & 3.457 & 3.457 & 5.58 & 5.61 \\
\hline & 1.21 & 1.70 & 0.197 & 0.183 & 1.11 & 1.46 & 2.837 & 2.830 & 4.35 & 4.40 \\
\hline & 0.08 & 0.25 & N.S & N.S & 0.06 & 0.06 & 0.111 & 0.110 & 0.04 & 0.04 \\
\hline
\end{tabular}

\section{CONCLUSION}

According to the obtained results in this investigation, cucumber grafting onto Jumbo rootstock using the yeast extract at $10 \mathrm{gm} / \mathrm{L}$ was the best treatment that could be recommended to obtain the highest yield as well as improve fruit quality, especially TSS\% and vitamin C of cucumber fruit in north delta area and other regions with similar agro-climate conditions.

\section{REFERENCES}

A O A C (1996). Official methods of analysis, $12^{\text {th }} \mathrm{ed}$. washington, DC: AOAC.

Abd-Alla, M. A. (2002). Effect of soil solarization, fertilizer sort and grafting on growth and productivity of cucumber crop ( Curcumis sativa, L.). Ph.D. Thesis, Fac. Agric. Kafr El-Sheikh, Tanta Univ. Egypt, PP, 98.
Abou El-Yazeid,A. (2011). Effect of Foliar Application of Salicylic Acid and Chelated Zinc on Growth and Productivity of sweet pepper ( Capsicum annuum L.) Under Autumn Planting .Research Journal of Agriculture and Biological Sciences, 7(6): 423-433.

Abou El-Yazied;Aand M. A. Mady(2011). Effect of Naphthalene Acetic Acid and Yeast Extract on Growth and Productivity of Tomato (Lycopersicon esculentum Mill.) Plants . Res. J. Agric. \& Biol. Sci., 7(2): 271-281

Amer, S.S.A. (2004). Growth, green pods yield and seeds yield of common bean (Phaseolus vulgaris L.) as affected by active dry yeast, salicylic acid and their interaction. J. Agric. Sci., Mansoura Univ., 29(3): 1407-1422.

Balakhnina, T.; A. Borkowska (2013). Effects of silicon on plant resistance to environmental stresses: review. Int Agrophys 27,225-232. 
Barnett, J.A.; R.W. Payne and D. Yarrow (1990). Yeasts characteristics and identification. Cambradge. University Press, London, pp: 999.

Bhupinder, S.; K. Usha (2003). Salicylic acid induced physiological and biochemical changes in wheat seedlings under water stress. Plant Growth Regul , 39: 137-141

Castelfranco, P.A. and S.I. Beale (1983). Chlorophyll biosynthesis recent advances and areas of current interest. Ann. Rev. Plant Physio., 34: 241-278.

Cherif, M; A. Asselin and Belanger, R.R. (1994) Defense responses induced by soluble silicon in cucumber roots infected by Pythium spp. Phytopathology, 84, 236-242

El.Ghamriny,E.A.; H.M.E. Arisha and K.A.Nour (1999). Studies in tomato flowering, fruit set, yield and quality in summer seasons.1-spraying with thamine, ascorbic acid and yeast. Zagazig. J. Agric. Res. 26 (5):1345- 1364.

El-Sayed,S.F.; H.A.Hassan; A.A.Abdel-Wahab and A.A. Gebrael (2014). Effect of grafting on the cucumber yield and quality under high and low temperature.J.Plant Production ,Mansoura Univ.,5(3):443-456.

El-Semellawy, E. M. H. (2005). Effect of grafting on growth and yield of watermelon plants grown under low plastic tunnels in Baltiem district. Ph.D.Thesis, Fac. Agric., Kafr Elsheikh, Tanta Univ., Egypt, 211p.

El-Tohamy, W.A., H.M. El-Abagy and N.H.M. ElGreadly (2008). Studies on the effect of Putrescine, Yeast and Vitamin $\mathrm{C}$ on growth, yield and physiological responses of eggplant (Solanum melongena L.) under sandy soil conditions. Australian Journal of Basic and Applied Science, 2(2): 296-300.

Epstein, E. (1994). The anomaly of silicon in plant biology. Proc. Natl . Acad. Sci., 91, 11-17

FAO.(2015) Statistics at FAO. Available online: www.fao.org

Fathy, S.L. and S. Farid (1996). Effect of some chemical treatments, yeast preparation and royal Jelly on some vegetable crops growing in late summer season to induce their ability towards better thermal tolerance. J.Agric. Sci., Mansoura Univ., 25(4): 2215-2249

Gomez, K. A. and A. A. Gomez (1984). "Statistically procedures for agricultural research". $2^{\text {nd }} \mathrm{Ed}$. John Wiely and Sons, PP. 680.

Guntzer,F.; C.Keller and J.D.Meunier (2012).Benefits of silicon for plant crops: areview. Agron.Sustain.Dev. 32, 201-213.

Hongli; L. W. Minglin; Y. Xianchang; W. Huasen; G. Junjie and Y. Chao (2003). Effect of different scions/rootstocks on quality of cucumber fruits in greenhouse. Sei. Agri. Sinica. 39 (8) : 1611-1616

Hu, C., Y. Zhu, L. Yang, S. Chen and Y. Huang (2005). Comparison of photosynthetic characteristics of grafted and ownroot seedlings of cucumber under low temperature circumstances. Acta Botanica Boreali-Occidentalia Sinica, 26(2): 247-253.
Huaifu, F, G. Shirong: Z. Runhua: L. Nana: C. Congcong and D. Changxia (2006). Effects of grafting on growth and physiological metabolism in cucumber seedlings under hypoxia stress. Acta Hort. Sinica, 33(6) : 1225-1230.

Ikeda, H. ; O. Shinji and A. Kazuo (1986). The comparison between soil and hydroponics in magnesium absorption of grafting cucumber and the effect of increased application of magnesium. Bull. Natl. Veg. Res. Ins. Japan, C9: 31-41.

Jonas, V.B. ; D.D. Vleesschauwer; and M.Höfte (2013).Towards establishing broad-spectrum disease resistance in plants :silicon leads the way. J. Exp.Bot. 64, 1281-1293.

Khedr, Z M.A. and S. Farid (2002). Response of naturally virus infected tomato plants to yeast extract and phosphoric acid application. Annals of Agric. Sci. Moshtohor. Egypt, 38(2): 927-939.

Kim, S. and J. Lee (1989). Effect of rootstocks and fertilizers on the growth and leaf mineral contents in cucumber (Cucumis sativus L.). ResearchCollection-Kyung Hee University (KoreaRepublic).

Kraig, E. and J.E. Haber (1980). Messenger ribonucleic acid and protein metabolism during sporulation of Saccharomyces cerevisiae. J. Bacterial., 144: 1098-1112.

Kubota, C., M. A. McClure, N. K. Burelle, M. G. Bausher, E. N. Rosskopf and D. O. Chellemi (2010). How to graft cucurbits. multi-state project 'Use of grafted seedlings for methyl bromide transition in U.S. open-field fresh vegetable production. Arizona University. Available at: http://cals. arizona.edu/ grafting/ howto/ cucurbits/grafting_methods.

Lee ,J.M. (2003). Advances in vegetable grafting. Chronica Horticulturae, 43: 13-19.

Lee ,J.M. and M.Oda (2003). Grafting of herbaceous vegetable and ornamental crops. Hort. Rev. 28:61-124.

Liang, Y. C; T. S. Ma, F. J. Li and Y. J. Feng (1994). Silicon availability and response of rice and wheat to silicon in calcareous soils. Soil Sci Plant Anal, 25, 2285-2297.

Liu,Z.X;Z.L.Bie, Y.Huang, A.Zhen, B.Lei and H.Y.Zhang (2012). Grafting onto cucuribita moschata rootstock alleviates salt stress in cucumber plants by delaying photoinhibition.Photosynthetica,50(1):152-160.

Ma, J.F. and N. Yamaji (2006). Silicon uptake and accumulation in higher plants. Trends Plant Sci. 11, 392-397

Mady,M. A. (2009). Effect of foliar application with salicylic acid and vitamin e on growth and productivity of tomato (lycopersicon esculentum, Mill.) plant. J. Agric. Sci. Mansoura Univ., 34 (6): $6735-6746$.

Mahmoud, T.R. (2001). Botanical studies on growth and germination of Magnolia (Magnolia grandiflora L.) Plants. M.Sc. Thesis, Fac. Agric., Moshtohor, Zagazig Univ., 103 pp. 
Marafon,A.C. and L.Endres (2013).Silicon:fertilization and nutrition in higher plants. Rev.Cienc.Agrar. $6,80-88$.

Metwally ,A ; I.Finkemeier , M.Georgi, K.J Dietz (2003). Salicylic acid alleviates the cadmium toxicity in barley seedlings Plant Physiol 132: $272-281$

Meuwly, p.; W. Molders; A. Buchala and J. Metraux (1995). Local and Systemic Biosynthesis of Salicylic Acid in Infected Cucumber Plants. plant physiol. 109: 1107-1114.

Ministry of agriculture and land reclamations (2015). agricultural Statistics: http://www.agr-egypt .gov.eg

Mohamed, F.H; K.E. Abd El-Hamed , M.W.M Elwan, M.N.E. Hussien (2014). Evaluation of different grafting methods and rootstocks in watermelon grown in Egypt. Sci. Hort. 168: 145-150.

Peterburgski, A. V. (1968). Hand book of Agronomic Chemistry. Kolop Publishing house, Moscow (in Russian). PP. 29-86.

Pulgar, G., G. Villora, D. Moreno and L. Romero (2000). Improving the mineral nutrition in grafted watermelon plants: nitrogen metabolism. Biologia Plantarum, 43(4): 607-609.

Rahmatian,A;M.Delshad and R. Salehi (2014). Effect of grafting on growth, yield and fruit quality of single and double stemmed tomato plants grown hydroponically. Hort. Environ. Biotechnol. 55(2):115-119

Rizwan; M.Ali; S.Ibrahim; M.Farid; M.Adrees; M.Bharwana; and S.A.etal (2015). Mechanisms of silicon-mediated alleviation of drought and salt stress in plants: a review. Environ.Sci.Pollut.Res. 22, 15416-15431.
Ruiz, J., A. Belakbir, I. LópezCantarero and L.Romero (1997).Leaf macronutrient content and yield in grafted melon plants. A model to evaluate the influence of rootstock genotype. Scientia Horticulturae, 71(3): 227-234.

Ruiz, J.M and L. Romero (1999). Nitrogen efficiency and metabolism in grafted melon plants. Scientia Horticulturae, 81: 113-123.

Said A. Shehata; Zakaria.F. Fawzy and Hassan R. ElRamady (2012) Response of Cucumber Plants to Foliar Application of Chitosan and Yeast under Greenhouse Conditions. Australian Journal of Basic and Applied Sciences, 6(4):63-71, ISSN 1991-8178.

Vicente, M.R and J.Plasencia (2011). Salicylic acid beyond defense: its role in plant growth and development. J Exp Bot, 62:3321-3338.

Williams, M; T.Senaratna ,K. Dixon and K. Sivasithamparam (2003). Benzoic acidinduces tolerance to biotic stress caused by Phytophthora cinnamomi inBanksai attenuate. Plant Growth Regul 41:89-91

Zhong, Y.Q. and Z.L. Bie (2007). Effects of grafting on the growth and quality of cucumber fruits. Acta Hort. 761, 341-347.

Zhu, J.; Z. L. Bie; Y. Huang and X. Y. Han (2006). Effects of different grafting methods on the grafting work efficiency and growth of cucumber seedlings. China Veg., 9: 24-25.

Zhu, Y. and H.Gong (2014). Beneficial effects of silicon on salt and drought tolerance in plants. Agron.Sustain.Dev. 34, 455-472.

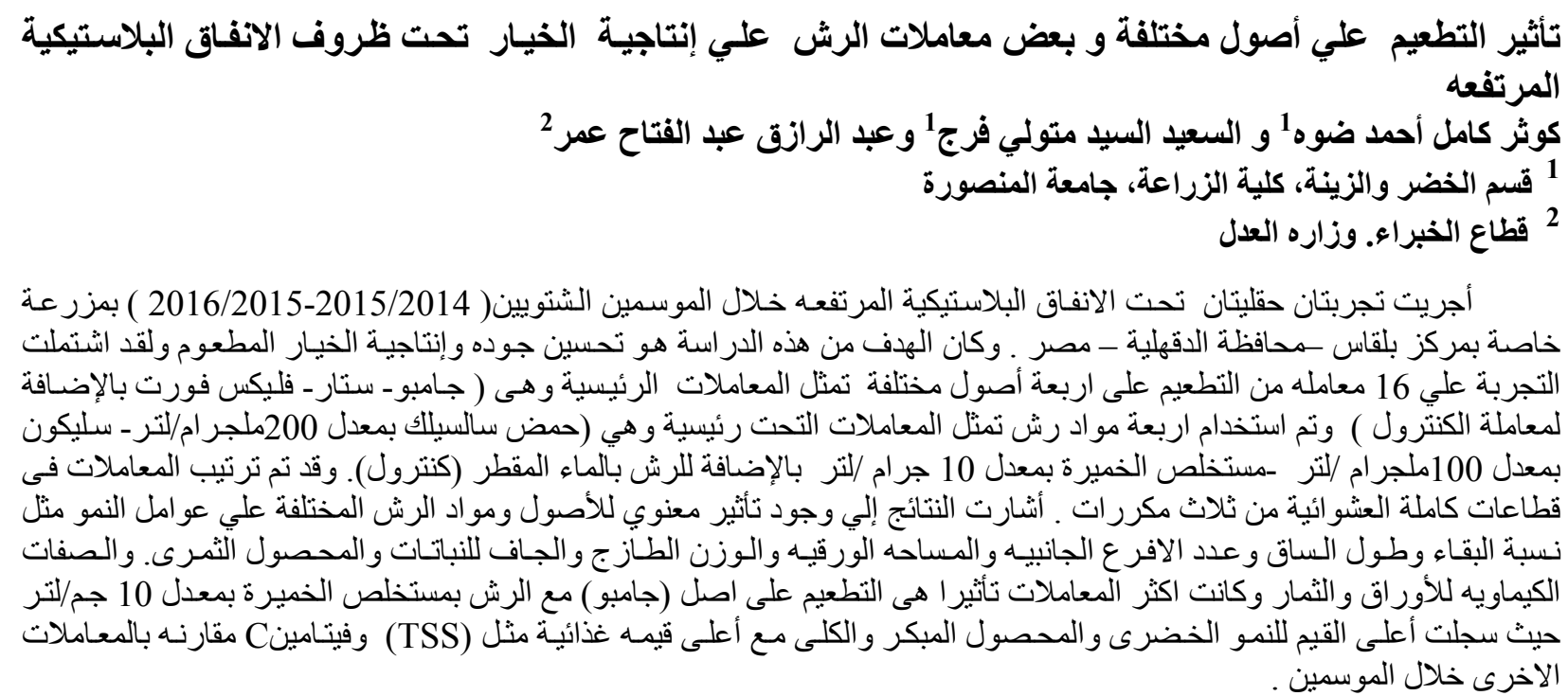

